\title{
УДОСКОНАЛЕННЯ ЛАНДШАФТНО- РЕКРЕАЩІЙНОГО СЕРЕДОВИЩА МІСТ ТА ПОЗАМІСЬКИХ ТЕРИТОРІЙ ШЛЯХОМ ВПРОВАДЖЕННЯ ВЕЛОСИПЕДНОЇ ІНФРАСТРУКТУРИ
}

\author{
Щурова В. А., канд. арх., дочент \\ Гарбар М. В., асистент \\ Украӥна, Київ, Київський національний університет будівництва і архітектури
}

DOI: https://doi.org/ 10.31435/rsglobal_ws/31102018/6172

\begin{tabular}{l} 
ARTICLE INFO \\
Received: 16 August 2018 \\
Accepted: 20 October 2018 \\
Published: 31 October 2018 \\
\hline KEYWORDS \\
landscape - recreation environment, \\
parks, \\
bicycle infrastructure, \\
tourist way, \\
bicycle parking, \\
building for bicycles.
\end{tabular}

\begin{abstract}
The classification of urban and suburban landscapes and recreation objects is given, and the expediency of using cycling transport as an independent within the territory of green plantations and transit in the general system of the city bicycle network is analyzed. Estimates of the number of parking lots for bicycles in city parks of different sizes are given. The results of the study are illustrated by the introduction of a project for the reconstruction of the park of culture and recreation them. M. Rylsky in Kyiv, Ukraine. Quantitative and qualitative indicators of improving the landscape and recreational environment of cities and outlying areas are identified by introducing bicycle infrastructure: normative data, radii of accessibility to destinations and services, the possibility of changing the type of operation and mode of operation from the capacity and conditions of the inhabitants' activity depending on the season and season load on city objects; the efficiency of communications in remote networks, functional optimality, convenience of communication, strengthening of the connection of the city with natural resources.
\end{abstract}

Citation: Щурова В. А., Гарбар М. В. (2018) Udoskonalennia Landshaftno-Rekreatsiinoho Seredovyshcha Mist ta Pozamiskykh Terytorii Shliakhom Vprovadzhennia Velosypednoi Infrastruktury. World Science. 10(38), Vol.1. doi: 10.31435/rsglobal_ws/31102018/6172

Copyright: (C) 2018 Щурова В. А., Гарбар М. В. This is an open-access article distributed under the terms of the Creative Commons Attribution License (CC BY). The use, distribution or reproduction in other forums is permitted, provided the original author(s) or licensor are credited and that the original publication in this journal is cited, in accordance with accepted academic practice. No use, distribution or reproduction is permitted which does not comply with these terms.

Вступ. Інтенсифікація інтелектуальної та управлінської діяльності, активний розвиток масових комунікацій є чинником, що визначає зміни у виборі пріоритетних напрямів дозвілля.

Знаходячись на позиціях екологічного підходу до проектування міського середовища, здається доцільним оцінити критерії якості міського середовища як ланки однієї системи. Екологічна інтерпретація міського ландшафту має розглядатись як екосистема, що знаходиться в постійному відновленні циклів, де кожен з елементів залежить від інших, і його зміни призводять до трансформацій у сусідніх з ним компонентах.

Ландшафтно-рекреаційне середовище включає в себе природні та штучно створені міські і заміські озеленені та водні простори в загальну архітектурно-планувальну та композиційну ієрархічну структуру. Зелені насадження мають велике значення як для повноцінного функціонування міста в цілому, так і окремої людини зокрема. В даній статті розглядаються засоби удосконалення різних за розміром об'єктів рекреаційного призначення в місті за рахунок впровадження велосипедної інфраструктури. 
Основний зміст. При формуванні мережі ландшафтних та рекреаційних територій населених пунктів слід виділяти: території загального користування (ділянки садово-паркового будівництва - парки, сади, сквери, бульвари; лісопарки; частково об'єкти природнозаповідного фонду); території обмеженого користування (ділянки житлової забудови, об'єктів громадського обслуговування, культурної спадщини, виробництва); території спеціального призначення (охоронювані природні території, озеленення санітарно-захисних та охоронних зон вздовж пішохідно-транспортних мереж, коридорів, сільськогосподарських та інших територій) (Рис. 1).

Питаннями організації ландшафтно-рекреаційного середовища міст займались такі вчені, як Ян Гейл, В. А. Нефедов, Н. Я. Крижанівська. Типологічні характеристики ландшафтних елементів міста розроблені І. Д. Родічкіним, туристичні об’єкти міських i позаміських рекреаційних територій висвітлені у наукових працях Т. Ф. Панченко.

Просування та розвиток велоінфраструктури в містах відображено в підручниках європейської програми в рамках проекту СC Intelligent Energy Presto; SFMTA Bicycle Parking: Standards, Guidelines \& Recommendations; Cycling in the Netherlands. Ministerie van Verkeer en Waterstaat. Published by: Ministry of Transport, Public Works and Water Management DirectorateGeneral for Passenger Transport, 2009; The city of Copenhagen`s bicycle strategy 2011 - 2025; The Kyiv City Development Strategy Until 2025 та ін.

Відповідно до статті 63 Закону України «Про охорону навколишнього природного середовища», статті 50 та 51 Земельного кодексу України рекреаційними зонами є ділянки суші i водного простору, призначені для організованого масового відпочинку населення і туризму. Відповідно до п. 3.4 Державних санітарних правил планування та забудови населених пунктів, затверджених наказом МО3 України від 19.06.1996 р. територія населеного пункту 3 урахуванням переважного функціонального використання поділяється на сельбищну, виробничу та ландшафтно-рекреаційну, що охоплює приміські ліси, лісопарки, лісозахисні смуги, водоймища, зони відпочинку та курортні зони, землі сільськогосподарського використання та інші, які разом з парками, садами, скверами, бульварами сельбищної території формують систему озеленення та оздоровчих зон.

Ландшафтно-рекреаційні території у межах міста являють собою мережу ділянок озеленених та інших відкритих просторів різного призначення, для яких допускаються заходи щодо:

- переосвоєння під іншу функцію: у виключних випадках, виділення окремих ділянок під забудову за умов урахування суміжності функцій (курортні, спортивні, культурнорозважальні, готельні комплекси;

- підвищення кількісних характеристик: насиченість територій об'єктами обслуговування відповідного типу;

- підвищення якісних характеристик.

Реконструкція ландшафтно-паркових територій з підвищенням рівня їх благоустрою, атрактивних якостей; розвиток інженерно-транспортної інфраструктури [1].
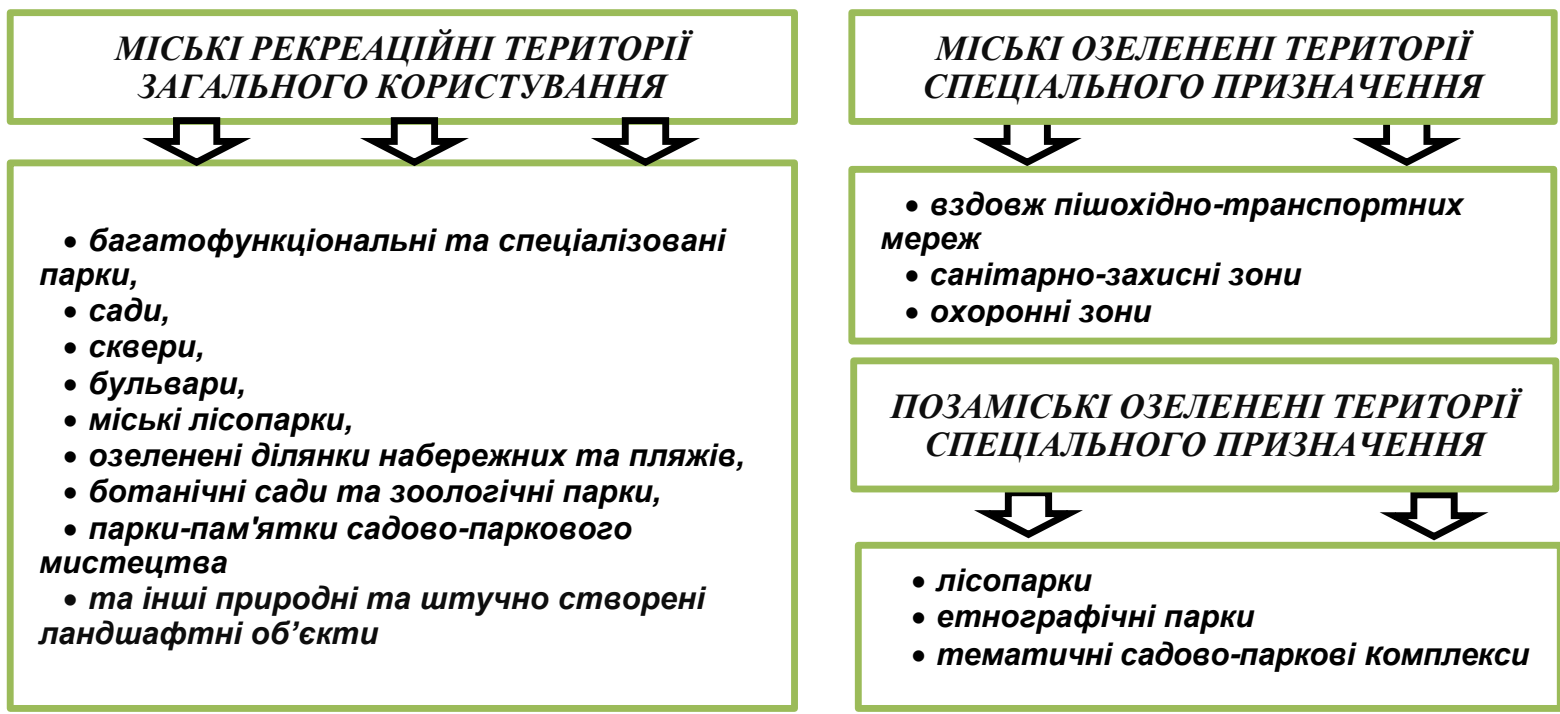

Рис. 1. Класифікація міських і позаміських ландмафтно-рекреаційних територій. 
Один 3 прикладів переоблаштування міста Києва під європейський формат - спроби розвинути велосипедну інфраструктуру Києва. Ще 2008 року у Київській мерії заявляли, анонсуючи конструкцію перших дорожніх смуг для велосипедів: «Велосипедні доріжки будуть побудовані не тільки уздовж лінії київського швидкісного трамвая. Вони будуть побудовані уздовж більшості доріг у спальних районах, а також парків і зон відпочинку, як у всіх нормальних європейських країнах» [2].

Для експертної оцінки об'єкта дослідження розроблено «Анкету опитування мешканців м. Києва», які користуються велосипедним транспортом, або хотіли б щоденно ним користуватись по мірі ліквідації суттєвих для них перепон (рис.1). Було опитано 162 респонденти: $62 \%$ - це люди віком до 25 років, $22 \%$ - 25 - 40 років, $16 \%$ - старше 40 років. $62 \%$ - жінки, що дало оптимальний варіант відповідей у зв'язку з пріоритетом безпечного пересування на велосипеді. 54\% не мають власного велосипеду, але $82 \%$ з усіх опитаних бажають мати власний велосипед, і 9\% лише готові користуватись муніципальним або прокатним велосипедом. Результати використано для обгрунтування необхідності формування повної велоінфраструктури, напрямки тяжіння, маршрути цільових поїздок, потреби в додаткових приміщеннях для обслуговування велосипеда і велосипедиста.

Так, наприклад визначено, що 94\% опитаних заважає використовувати велосипед в Києві відсутність якісної веломережі та високий ступінь небезпеки; $76 \%$ респондентів зазначили у перепонах відсутність споруд та обладнання для зберігання велосипедів; 92\% вважають, що необхідно розвивати велоінфраструктуру в рекреаційних зонах міста та на позаміські території; 3 додаткових приміщень при спорудах для велосипедів 70\% респондентів вважають за необхідне влаштування санітарних вузлів, 86\% - майстерень для обслуговування велосипеда. 52\% вважають за потрібне поєднувати споруди для велосипедів з медпунктом. Шафи і душові стали у потребі $26 \%$ респондентів. Ці приміщення доцільні як додаткові функції споруд для велосипедів при місцях прикладення праці та навчання або на туристичних маршрутах.

Для занять спортом місцеві мешканці вибирають будь-які невеликі паркові масиви, сквери хоча краще, звичайно, більш значні по території. Це обумовлено, в першу чергу, тим, що парковий ландшафт, що знаходиться в міській забудові, постійно піддається агресивній дії на нього транспортних магістралей, наповнених вихлопними газами, шумом і пилом. I чим більше по площі парковий масив, тим ефективніше він здатний очищати і оздоровлювати навколишнє повітря. Для занять спортом це найбільш важливий показник. Другий по важливості принцип проектування садово-паркового ландшафту - свобода орієнтації в просторі.

Згідно даних аналізу світового досвіду, до найбільш відвідуваних спеціалізованих парків відносяться зоопарки, парки-виставки, розважальні і спортивні парки. Гідропарки і лугопарки організовують в зонах рік, озер і водойм для масового відпочинку. Великі площі таких парків вимагають використання додаткових видів немоторизованого транспорту для огляду експозиції. Так, наприклад у королівському парку квітів Кекенгоф (нід. Keukenhof) у Нідерландах розташованому на 32 гектарах землі для туристів, що мають обмеження у часі для огляду величезних квіткових галявин працює прокат велосипедів.

Згідно з існуючою в Україні номенклатурою структурних елементів мережі природноландшафтних, рекреаційних та інших озеленених територій в межах населених пунктів в залежності від свого призначення й місця розташування розділяють на території загального, обмеженого та спеціального користування [6].

До ландшафтних територій загального користування населених пунктів, які мають бути забезпечені якісною велоінфраструктурою, відносяться: багатофункціональні та спеціалізовані парки, сади, сквери, бульвари, міські лісопарки, озеленені ділянки набережних та пляжів, ботанічні сади, зоологічні парки, парки-пам'ятки садово-паркового мистецтва та інші природні і штучно створені ландшафтні об'єкти.

За наявності визначних природних ландшафтів, історико-культурних заповідників, пам'яток природи і архітектури на території природно-заповідних об'єктів слід створювати своєрідні туристичні шляхи, які можуть включати екскурсійні природно-культурні об'єкти, туристичні заклади, центри обслуговування, майданчики для відпочинку тощо [3].

Питома вага території функціональних елементів туристичної зони повинна становити, у \% від загальної площі: забудова $-8-10$, садово-паркові ділянки $-3-4$; стоянки $-2-3$; шляхи - 5-7; туристичні угіддя (ліси, водойми, гори) та ареали концентрації об'єктів огляду культурної спадщини $-75-80$ (рис. 2). 


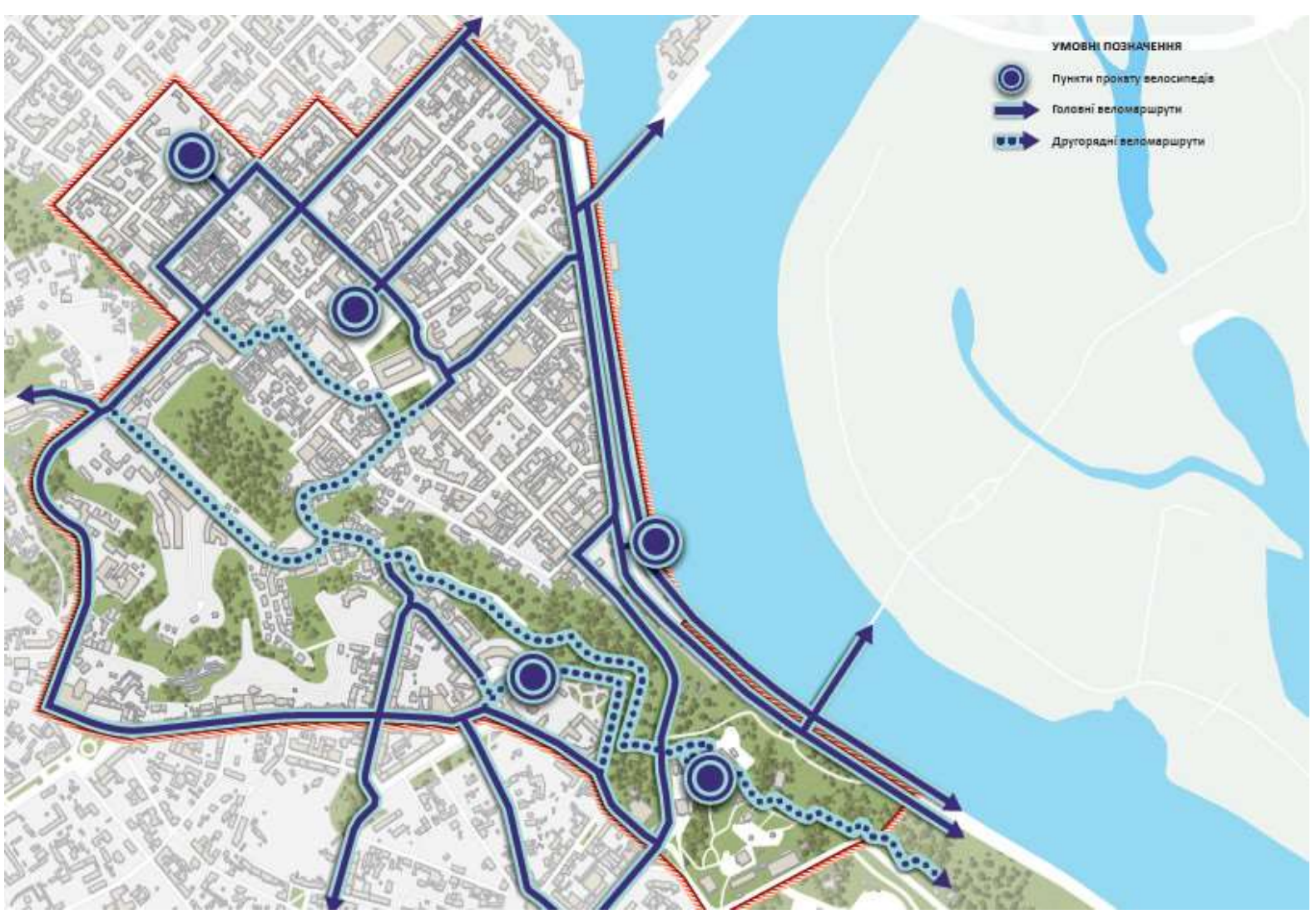

Рис. 2. Схема веломаршрутів «Київ самобутній» у складі туристичного шлляху на Дніпровських схилах м. Києва [4]

Сквери та бульвари, призначені для короткочасного відпочинку, прогулянок та пішохідного руху. Бульвари створюють на магістралях набережних, у громадських центрах, вздовж проспектів при інтенсивному пішохідному рухові. Вздовж основного пішохідного напрямку доцільно влаштовувати безпечні велосипедні доріжки, відмежовуючи їх від транспортного руху. Місця підземних переходів можуть стати зручними місцями для паркування велосипедів та приміщень для їх обслуговування.

Сквери прикрашають міські площі, вулиці та відносно невеликі розміри: від 0,5 до 2 га. Якщо вони знаходяться біля видовищних споруд, офісних будівель, освітніх закладів тощо, то стають місцями для влаштування споруд та обладнання для збереження власних $\mathrm{i}$ муніципальних велосипедів.

Дитячі парки у великих і значних містах, призначені для ігор, розваг, фізкультури i культурно-просвітніх занять дітей, що мають розміри від 3 до 20 га, придатні для влаштування велосипедних споруд, доріжок і пунктів прокату.

Міські парки (зокрема, парки культури та відпочинку), міські сади - найбільш масовий тип парку, в якому відпочинок у природному оточенні поєднується з розважальними заходами. За розміром вони можуть бути: малими - 25 га, середніми - 100 га, великими - 500 га й значними більше 500 га $з$ часом доступності на транспорті - 15 - 20 хвилин. [5] Парки мають кілька зон: основна - зона тихого відпочинку, зона масових заходів, культурно-просвітня, фізкультурнооздоровча, дитяча, господарська. В таких парках велосипед може стати в нагоді як для розважальної і фізкультурно-оздоровчої мети, так і для швидкого пересування до бажаної функціональної зони чи огляду усього парку. Головний вхід в парк зазвичай розташовують 3 боку найбільшої кількості відвідувачів. Поруч передбачають площу для громадського, особистого автотранспорту i пункти прокату велосипедів. Споруди для велосипедів 3 супутнім обслуговуванням велосипеду і велосипедиста також можуть влаштовуватись і біля другорядних виходів з парку або у найбільш віддалених точках від основного входу.

Згідно нормативних даних кількості відвідувачів парків встановлених в ДБН В.2.212:2018 можна розрахувати загальну кількість необхідних стоянок для велосипедів. (табл.1) Стоянки для велосипедів можна розподілити на споруди довготривалого зберігання та стійки для короткочасних зупинок на території всього парку. 
Таблиця 1. Кількість стоянок для велосипедів в міських парках різного розміру.

\begin{tabular}{|l|c|c|c|c|c|}
\hline Tип парку & Розмір, га & Кількість & \multirow{2}{*}{$\begin{array}{c}\text { Кількість } \\
\text { осіб/га }\end{array}$} & \multirow{2}{*}{$\begin{array}{c}\text { відвідувачів, } \\
\text { особи }\end{array}$} & \multicolumn{2}{|c|}{\begin{tabular}{c} 
Кількість стоянок для \\
велосипедів (\% від \\
\cline { 5 - 6 }
\end{tabular}} & & & & $10 \%$ & $30 \%$ \\
\hline маликості відвідувачів), шт
\end{tabular}

В середньому радіус пішохідної доступності до периферійних спеціалізованих парків визначають 1,5 - 2,0 км. При використанні велосипеду радіус збільшується від 8 км до 30 км. Використання власних велосипедів обгрунтоване при доступі від житла до місць відпочинку, а також як засіб швидкого доступу до об'єктів різного призначення в межах ландшафтного об'єкту. При наявності розгалуженої велосипедної інфраструктури в місті зв'язок житло рекреаційне середовище, зона відпочинку - житло може мати замкнений цикл без пересадки на інший вид транспорту.

У проекті реконструкції парку культури і відпочинку ім. М. Рильського в м. Києві (парк житлового району) запропоноване сучасне бачення паркового середовища, як частини великого міста. Парк займає територію більше 140 га. Більша частина парку має природній ландшафт із складним рельєфом та комплексом озер. Територію парку можна використовувати для різноманітних занять спортом, зокрема для велосипедних змагань на місцевості. Розроблена нова велосипедна мережа парку, запропонована система споруд та обладнання для велосипедів. Проектування здійснювалося з використанням методологічних підходів та специфікою дизайнприйомів формування велосипедної інфраструктури (рис.3).

У межах парку проектна велосипедна інфраструктура складається 3 велосипедних доріжок, стоянок довготривалого та короткочасного зберігання для велосипедів, пунктів прокату. В зоні головного входу - центральної площі передбачена багатофункціональна споруда для муніципальних велосипедів (прокат) з зоною обслуговування та ремонту, шафами для зберігання особистих речей, туалетами, душовими. В зимовий період в споруді можна зберігати велосипеди всього парку. Стоянки для велосипедів необхідно передбачати в різних функціональних зонах парку, на рівновіддаленій відстані між собою.

На думку замовників - Громадської організації «Всеукраїнський студентський парламент» ефективність впровадження полягає у реалістичності та економічності наданих пропозицій щодо підвищення якості архітектурного середовища парку культури і відпочинку ім. М. Рильського у м. Києві. 


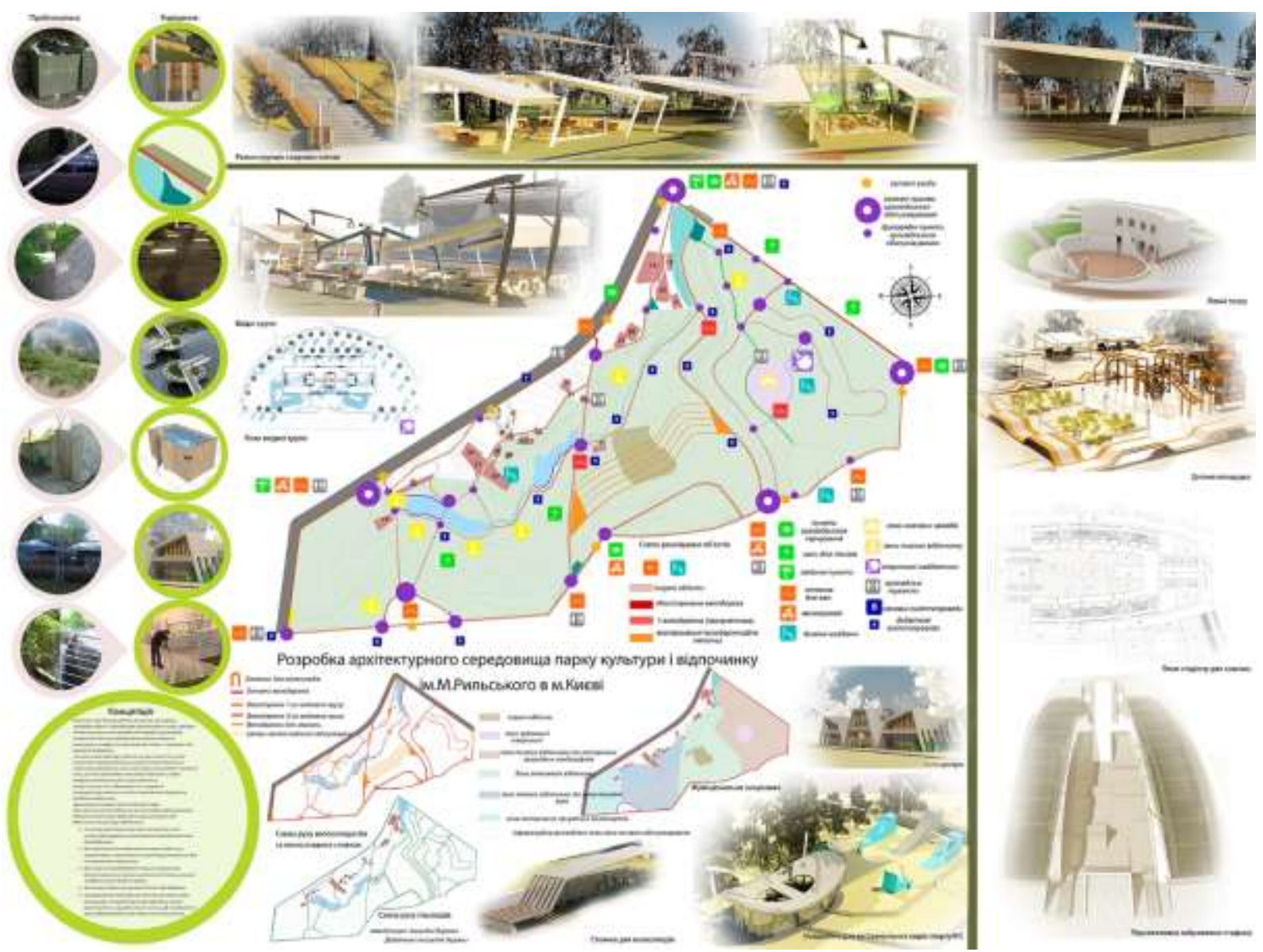

Рис. 3. Проект реконструкиії парку культури і відпочинку ім. М. Рильського в м. Києві (розробка автора Гарбар М. В.)

Таким чином, можна визначити алгоритм архітектурно-планувального моделювання парку: розробка концепції парку; планувальної структури території парку; сценарне моделювання процесів, які можуть розгортатися в проектованому архітектурному середовищі продовж доби, в робочі і вихідні дні, в різні пори року. На основі тематичного зонування складається схема функціонального використання території парку. Окреслюються маршрути i обдумується характер руху людини в просторі, намічається послідовність зорових кадрів, які може побачити людина, дотримуючись заданих траєкторій руху. Схема руху людини в просторі позначається шляхом виділення пішохідних, бігових, велосипедних, екскурсійних, водних та технологічних маршрутів. Комунікаційна зона - мережа пішохідного руху; мережа бігових доріжок; мережа велосипедних доріжок; мережа руху екскурсійного електротранспорту; мережа руху обслуговуючого автотранспорту; пункти прокату транспортних засобів; місця зберігання і технічного обслуговування транспортних засобів.

Потреба в пошуку засобів удосконалення ландшафтно-рекреаційного середовища міст шляхом впровадження велосипедної інфраструктури 3 підкресленням необхідності влаштування споруд для велосипедів визначається новими соціально-економічними, екологічними, містобудівними умовами в обставинах нагальної необхідності вирішення транспортних, функціонально-планувальних і архітектурно-дизайнерських задач формування оптимального, комфортного міського середовища.

Європейські схеми містобудування приймають до уваги той факт, що пріоритетом для велосипедистів $\epsilon$ якомога пряміше сполучення за основними маршрутами ïx руху $\mathrm{i}$ що облаштування протяжних об'їзних доріг призведе до відмови велосипедистів від їх використання. Концепція пропонує широке використання парків та зелених зон для організації велоруху.

\section{Висновки.}

1. Велосипедний транспорт можливо використовувати як самостійний в межах території зелених насаджень, так і як в загальній системі велосипедної мережі міста, як транзитний. Це призведе до збільшення зацікавленості в відвідуванні парків великих міст різними шарами населення. Також це $\epsilon$ найбільш реальний та економічно виправданий захід. 
2. В зонах відпочинку дуже доречним $є$ співіснування велосипедистів та пішоходів.

3. У зв'язку із невеликою швидкістю перших, у пішоходів не виникає психологічного відторгнення цього виду транспорту. До того ж, велосипедний транспорт є дуже корисним для здоров'я у будь якому віці.

4. Серед кількісних показників на розміщення велосипедних споруд у ландшафтнорекреаційному середовищі впливають нормативні дані, радіуси доступності до пунктів призначення та обслуговування, можливість зміни виду експлуатації та режиму функціонування від місткості та умов діяльності мешканців у залежності від пори року та сезонного навантаження на міські об'єкти. В залежності від розміру парку змінюється кількість стоянок для велосипедів. В малому парку - це може бути одна стоянка в центральній його частині, в середньому та великому парку додаються стоянки через кожні 1000-1500м, або в різних його функціональних зонах.

5. До якісних показників можна віднести ефективність зв'язків у веломережі, функціональну оптимальність, зручність сполучення, підсилення зв'язку міста з природними ресурсами.

Для реалізації комунікативної функції необхідно передбачати формування розвинутих пішохідних зон та зон користування велосипедним транспортом, що сприятиме покращенню екологічної ситуації та охарактеризується як «зелена мобільність» міста.

\section{ЛIТЕРАТУРА}

1. Плешкановська А. М. Функціонально-планувальна оптимізація використання міських територій. К.: Вид., 2005. -190 с.

2. Булах Т. Європейська модерність та європейське майбутнє / С. Шліпченко, І. Тищенко (упор.) (Не)Задоволення публічними просторами. Урбаністичні Студії ІІІ. - К.: Всесвіт, 2017. - С. 317 320.

3. Панченко Т. Ф. Туристичне середовище: архітектура, природа, інфраструктура (Монографія) / Т. Ф. Панченко. - К.: Логос, 2009. - 176 с.

4. «Міська концепція «Київ Самобутній» - шлях до сталого розвитку території», Київська міська державна адміністрація, Київмістобудування, Проектгенплан, буклет, 2013. - 49 с.

5. Шилова Т. О., Омельяненко М. В. Планування міст і транспорт. - К.: КНУБА, Навчальний посібник, 2013

6. ДБН В.2.2-12:2018 Планування і забудова територій. - К.: Мінрегіон України, 2018 